\section{$1 \mathrm{I} 1400$}

キモトリプシンインヒビター 2 の熱変性過程の動力 学シミュレーション

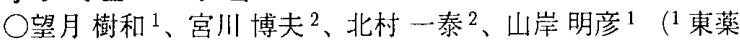
大生命、2 大正製薬)

並列型動力学専用コンピュータ（以下MDエンジン）を用い、原子の 相互作用や熱などの力をパラメータとして与え、蛋白質分子の動きを 全原子モデルを用いて水分子を含む分子動力学によってシミュレート した。この方法を用いる事により、実際の蛋白を用いた実験ではわず かな時間で終わってしまう変化を、フェムト秒の単位でその過程や構 造を可視化することができる。

今回の春験では、アミノ酸残基 64 の蛋白質 chymotrypsin inhibitor 2 (Cl2）を用いその熱変性過程をシミュレートした。エネルギーの計 算システムとしてアプリケーション「AMBER version6』を用いた。 変成させる蛋白は NMRにより構造が決定されたCI2（PDBエント リー名:1YPC.pdb）の全原子モデルを用い、CI2 分子の周りに箱状に 水をつけた。周期的境界条件を付加し、通常の動力学シミュレーショ ンで多用されるカットオフ近似は行わなかった。これは従来のシミュ レーションよりもさらに精密な結果を期待するものである。これらの 条件に、熱変性の為の温度を $300 \mathrm{~K}$ から $700 \mathrm{~K}$ まで $100 \mathrm{~K}$ の幅で五種 類用意し、それぞれ 2000psのシミュレーションを行った。RMSDの 増加や二次構造の崩壊を解析し、温度每に比較する事により、CI2の 熱変性過程の詳細を明らかにした。

この研究は科学技術振興事業団バイオインフォマティクス推進事業の 助成をうけて行われた。

K.Mochizuki, H.Miyagawa, K.Kitamura, A.Yamagishi : Molecular dynamics simulation of thermal denaturation of chymotrypsin inhilitior 2

\section{0}

動的なモード座標系として表現される蛋白質のダイ ナミクス

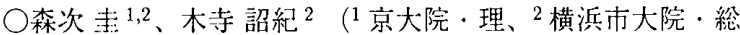
合理学)

蛋白質のダイナミクスは、その立体構造と機能発現との相関を理解す る上で重要である。計算機シミュレーションによりダイナミクスを理 解する方法として、これまで基準振動解析や主成分解析などの調和近 似が用いられてきた。これらの方法では分子内の代表的な運動を抽出 できる反面、時間軸に沿った運動がどのような要因で起こるのかを理 解することはできない。本研究では、蛋白質の運動を時分割で計算さ れる主成分モードの時間变化として解析し、その变化を非線形性の寄 与として説明した。

時分割で主成分モードを計算した場合、調和近似のパラメータである 平均構造とモードの方向、固有値は非線形項の寄与により時間変化す る。その変化は、線形なモードで張られる座標系の並淮と回転として 表現できる。非線形項を掑動とみなした場合、その応答としてモード の並進と分散共分散行列の変化が起こり、更に、分散共分散行列の变 化がモードの回転を引き起こす。時間空をずらしながら主成分解析の 計算を繰り返すことで、モード座標系の並進と回転を時系列として観 測し、非線形項による掑動という観点から解析を行った。

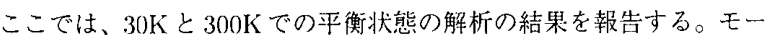
ドの並進は、低温では振動的であるのに対し、高温では、非線型項が 数 100ps の相関時間で寄与することにより、第 1 モ一ドの方向に舆い 時間スケールで搪散的な運動をしていた。一方、モードの回転は一般 に高温のほうが大きいが、低温でも共鳴のために大きくなる場合が あった。しかし、回転の大きさが同じ場合でも、共鳴による回転は比 較的短い相関時間を持つ非線形項の寄与で起きていた。これらの結果 加、蛋白質の構造変化は、固有値の大きい少数のモードの回転によ り、大きな邉移エネルギーの川を避けながら小さな遷移エネルギーの 谷をたどって別の構造に行きつく過程として理解できる。

K. Moritsugu and A. Kidera : Dynamies of Proteins Represented as Dynamic: Mode Coordinates

\section{$1 \mathrm{I} 1415$}

protein Gのアンフォールディング過程におけるモ ジュールの役割

○江口 详也、高橋 健一、郷 通子（名大·院理·生命理）

タンパク質はそれぞれ特定の天然構造を持つが、これが変性状態から どのようにフォールドするかを解明するため、protein GのB1ドメイ ンを対象に分子動力学計算を用いて天然構造からのアンフォールディ ング過程を解析した。球状タンパク質の天然構造は、モジュールと呼 ばれる一次構造上連続した 15 残基程度のコンパクトな部分棈造に分 割できる。モジュールはモジュール境界自動同定法を用いて同定され る。protein GのB1ドメインの天然構造では 5 個のコンパクトなモ ジェールが集まって球状ドメインを形成している。この階層的構造が アンフォールディング過程で、どのように壊れていくのかを追跡する ために、分子動力学計算で得られたアンフォールディングシミュレー ションの各時間の立体構造に対して、モジュール境界を同定した。そ の結果、モジュール境界は多くの時間で、天然構造に対して同定され た場所の近くに存在し続けることが分かり、疎水性コアが崩れた構造 でも天然のモジュール構造は緩やかに保たれていることが分かった。 さらに、アンフォールディング過程における各時間でのモジュール内 のコンタクトとモジュール間のコンタクトの数を比べたとき、時間と 共に減少はするが前者の方が後者よりもよく保存されていた。比較の ために、モジュールの真ん中の残基から隣のモジュ一ルの真ん中の残 基までのセグメントを偽モジュールと定義し、モジュール内のコンタ クトと偽モジュール内コンタクトを比べると、明らかに前者の方が 6 残基以上離狆た残基とのコンタクトを多く持筥けていた。これらの ことから、アンフォールディング過程でタンパク質は、まずモジュー ル間の相互作用が減少しお互いに離れていきアンフォールドしていく が、天然構造で同定されたモジュールごとにはまとまっており、コン パクトな構造を保ち続けていることがわかった。

Tatsuya Eguchi, Ken-ichi Takahashi, Mitiko Go: A role of the modules in simulated unfolding processes of protein $\mathrm{G}$.

\section{5}

分子動力学法を用いた Btk タンパク質の PHドメイ ンの基質認識に関する研究

○石田 敬義 1 、中村 周吾 ${ }^{1}$ 、若松猪策無 ${ }^{2}$ 、福井 泰久 2 、清 水謙多郎 ${ }^{1}$ ( ${ }^{1}$ 東大院・農·応用生命工学、 2 東大院・農・応 用生命化学:

Btk(Bruton's tvrosine kinase) タンパク質は、B 練胞の分化に㧈 けるシグナル伝垟に関わるタンパクチロシンキナービである。Btkの PH(Pleckstrin Homology) ドメインは、細胞膜に埋まっているホスファ チジルイノシトール-(3,4,5)-3リン酸 $(\operatorname{Ptd} \ln s(3,4,5) \mathrm{P} 3)$ を特異的に認 識し、結合する機能を持つ。この結合を経ないと Btkは活性化されな いことから、その特異的な基質結合は Btkの活性化において必須であ ると考えられている。現在、BtkのPHドメインに関する立体構造は、 Protein Data Bankにイノシトール-(1,3,4,5)-4リン酸 $(\operatorname{Ins}(1,3,4,5) P 4)$ との複合体構造、及び基質のついていない free な構造が登録されてい るが、PHドメインが、どのような構造変化を経て基質を認識し結合 するのか、またそのダイナミクスが基質認識における特異性にどのよ うに関わってくるのかということについての詳細な議論はなされてい ない。そこで本研究では、基質認識過程におけるPHドメインのダイ ナミクスを調ベ、基質特異性の要因を残基レベルで明らかにするため に、分子動力学計算によるシミュレーションを試みた。

シミュレーションは、1）基質がない状態でのPHドメインの運動 を解析するために、基質のついていない freeな PHドメイン構造、2) 基質認識過程における運動を調べるために、freeな PHドメインの適 当な位置に基質 $(\operatorname{Ins}(1,3,4,5) \mathrm{P} 4)$ 省配置した構造、3）基質認識にお けるグリセロール骨格とアシル鎖の寄与を調べるために、frec な $\mathrm{PH}$ ドメインの適当な位置に基質 (PtdIIns $(3,4,5) \mathrm{P} 3)$ を配置した構造、の 3 種類を初期構造として行い、それぞれのシミュレーション途中での 構造変化や動的特性を比較、考察した。分子動力学計算は、AMBER version7.0)用い、上記の各構造について 2nsのシミュ.レーションを 行った。

T.Ishida, S.Nakamura, I.Wakamatsı, Y.Fukui, K.Shimizu : MD simulation study of a specific substrate binding mechanism of Btk's $\mathrm{PH}$ domain. 